\title{
Infective pentastomid larvae from Pygocentrus nattereri Kner (Pisces, Characidae) from the Miranda River, Pantanal, Mato Grosso do Sul State, Brazil, with notes on their taxonomy and epidemiology
}

\author{
Suely C. Giesen ${ }^{1}$, Ricardo M. Takemoto ${ }^{1}$, Frikkie Calitz ${ }^{2}$, Maria de los Angeles Perez Lizama ${ }^{1}$ and \\ Kerstin Junker ${ }^{3}$ \\ ${ }^{1}$ Universidade Estadual de Maringá, Maringá, Paraná, Brazil; \\ ${ }^{2}$ Agricultural Research Council-Biometry, Pretoria, South Africa; \\ ${ }^{3}$ Agricultural Research Council-Onderstepoort Veterinary Institute, Onderstepoort, South Africa
}

\begin{abstract}
During parasitological surveys of freshwater fish from the Miranda River, Brazil, 199 Pygocentrus nattereri Kner (Characidae) were caught. Two pentastomid families, Subtriquetridae Fain, 1961, represented by its single genus Subtriquetra Sambon, 1922 , and Sebekidae Sambon, 1922, represented by three genera, were present. Free-living larvae of Subtriquetra subtriquetra (Diesing, 1835) were collected from the swim bladder. Encysted larvae of Alofia Giglioli, 1922 were found in the abdominal cavity, chambers of the heart, musculature, on the surface of the gonads and swim bladder. Some Alofia larvae were moving freely in the swim bladder. Larvae of Sebekia Sambon, 1922 were encysted in the musculature. Some larvae of Leiperia Sambon, 1922 were found encysted in the musculature and on the surface of the pyloric caeca, whereas others occurred free in the abdominal cavity. In some of the latter, the head was buried deep in the wall of the intestine, stomach or ovaries, whereas the rest of their body remained free. Infective pentastomid larvae were present throughout the year with an overall prevalence of $77 \%$. Both prevalence and intensity were higher in members of the Sebekidae than in Su. subtriquetra, possibly due to the latter's mode of transmission and its high pathogenicity. No sex-related, statistically significant differences $(p>0.05)$ in prevalence or abundance were found. Fish weight and length had significant but weak positive correlations $(\mathrm{r} \leq 0.27)$ with the abundance of pentastomid larvae, possibly reflecting an increased likelihood of prior exposure in older fish. Parasite abundance had no significant effect on host body condition ( $p \geq 0.69)$. A higher prevalence and monthly mean abundance of pentastomids were seen in the dry season and might be due to increased host densities as habitats dry up. Pygocentrus nattereri represents a new intermediate host record for the genera Alofia, Leiperia and Subtriquetra.
\end{abstract}

Keywords: Pentastomida, survey, Sebekidae, Subtriquetridae, freshwater fish, piranhas, South America

Pygocentrus nattereri Kner (Characidae), often reported as Serrasalmus nattereri (Kner), is a carnivorous fish and one of the main predators in Neotropical freshwater ecosystems (Carvalho et al. 2003). It is common and widespread in the Miranda River basin and lives in schools of up to 30 individuals (Sazima and Machado 1990). To date, the pentastome fauna of P. nattereri is poorly studied, and data on the effect of these endoparasites on their host are scant.

Pentastomids are a small, still somewhat neglected group of internal parasites, comprising approximately 130 species (Almeida and Christofferson 1999, Riley et al. 2003). They were first described in crocodiles more than a century ago and fish were assumed to be intermediate hosts from an early stage (Junker et al. 1998a). Two families are currently recognized from crocodilian hosts; adults of species of the Subtriquetridae Fain, 1961 para- sitise the nasopharyngeal region of crocodilians, whereas those of the Sebekidae Sambon, 1922 invade the trachea, bronchioles and lungs of their final hosts, and have been reported from crocodilian as well as chelonian hosts (Winch and Riley 1986a,b, Riley et al. 1990, 1997, Riley 1994, Junker and Boomker 2002). Shipley (1898) was one of the first to report on pentastomids in South American crocodilians.

Presently, the following pentastomids have been reported from alligatorid crocodilian hosts in Brazil: Alofia platycephala (Lohrmann, 1889) and Sebekia microhamus Self et Rego, 1985 from Caiman crocodilus (Linnaeus) (Self and Rego 1985), as well as immature and larval forms of Leiperia gracilis Heymons et Vitzthum, 1936 (syn. Pentastomum gracile Diesing, 1836, in part) from Ca. crocodilus (syn. Ca. sclerops Schneider) and, possibly, Melanosuchus niger (Spix) (syn. Ca. niger Spix) 
(Heymons and Vitzthum 1936). Sebekia acuminata Travassos, 1924 and S. samboni Travassos, 1924 were listed from unknown crocodilians in Matto Grosso State (Travassos 1924). Three of these, L. gracilis, S. acuminata and $S$. samboni, are considered species inquirendae (Riley et al. 1990). A further sebekiid reported from Brazil, Diesingia megastoma (Diesing, 1836), parasitises chelonian hosts (Diesing 1836, Sambon 1922, Junker et al. 2003).

Two sebekiid genera have been recorded from fish intermediate hosts in Brazil: L. gracilis from Salminus brasiliensis (Cuvier) [syn. S. brevidens (Cuvier)] (Characidae), Hoplias malabaricus (Bloch) (Erythrinidae) and Brachyplatystoma sp. (Pimelodidae) (Rego and Eiras 1989), S. oxycephala (Diesing, 1836) from P. nattereri, Pseudoplatystoma corruscans (Spix et Agassiz) (Pimelodidae) and Phalloceros harpagos Lucinda (Poeciliidae) (Rego and Eiras 1989, Almeida et al. 2010), and Sebekia sp. from Hemisorubim platyrhynchos (Valenciennes) (Pimelodidae) (Guidelli et al. 2003). De Campos et al. (2008) and Barros et al. (2010) reported on unidentified pentastomids in Pseudoplatystoma fasciatum (Linnaeus) and $P$. nattereri, respectively.

To our knowledge, the only report of a subtriquetrid in South American fish dates back to J. Natterer, who found Subtriquetra subtriquetra (Diesing, 1836) (syn. Pentastomum pusillum Diesing, 1856) in the intestine of a female 'Acara coscudo (?) (Chromidae)' in Brazil (Shipley 1898, Sambon 1922, Holl 1928). As far as is known, fish acquire sebekiid infections when ingesting eggs (Riley 1986), whereas species of Subtriquetra Sambon, 1922 are transmitted through their uniquely free-living primary larva (Vargas 1975, Winch and Riley 1986b). Fish brushing against these primary larvae are invaded percutanuously (Winch and Riley 1986b).

Pentastomids have the potential to cause economic loss in aquaculture (Almeida et al. 2010) and crocodile farming systems that rely on fish as a natural food source (Boyce et al. 1984, Ladds and Sims 1990, Gairhe 2007), and have potential as zoonotic diseases. Species of both Leiperia Sambon, 1922 and Sebekia Sambon, 1922 have been reported from humans (Fain 1975, Mairena et al. 1989). Despite this, little is known about the occurrence and distribution of pentastomid larvae in freshwater fish.

In this paper we describe and illustrate infective larvae of two families of the Pentastomida recovered from P. nattereri in Brazil, present data on their epidemiology and compare our findings with reports on fish hosts in other geographic regions.

\section{MATERIALS AND METHODS}

\section{Study area}

Two hydrological seasons can be identified in the Pantanal. The period from January to March is characterized by the onset of flooding and is referred to as 'dry-flooding', since water levels still remain low. Full flood levels are reached during April to June, after which the water begins to recede ('flood-drying') (Carvalho et al. 2003).

\section{Parasite collection}

From April 2004 to March 2005, a total of 199 P. nattereri (76 males, 123 females) was collected on a monthly basis in the Miranda River, near the Base de Estudos do Pantanal of the Universidade Federal do Mato Grosso do Sul, municipality of Corumbá (19³4'36"S; 5701'05"W), Mato Grosso do Sul State, Brazil. Monthly sample size varied between 7 and 40, and no fish were caught in August 2004 and February 2005. Initially, fish were caught using baited line and rod, and transported back to the laboratory where they were kept in a reservoir with well aerated water. Fish were anesthetized with benzocain and killed by decapitation. Later during the study, fish were caught with seine nets, and identified and processed for parasite recovery in the field. Prior to dissection, fish were weighed to the nearest gram and their overall length was measured to the nearest 0.5 of a centimetre. A body condition factor $(\mathrm{k})$ was determined using the following formula: $\mathrm{k}=$ (weight in grams)*100/(length in $\mathrm{cm})^{3}$, whereby heavier fish for a given length would have a higher condition factor (Canada Department of Fisheries and Oceans Animal-User Training Template 2004).

Viscera were removed, placed in separate petri dishes with $0.65 \%$ saline and examined under a stereoscopic microscope. Similarly, the abdominal cavity and musculature were examined. All pentastomids were fixed in hot AFA, and subsequently stored in $70 \%$ ethanol. For identification, specimens were mounted and cleared in Hoyer's medium. Drawings and measurements were made with the aid of a Nikon YS2 microscope equipped with a drawing tube. Figure 1 illustrates hook and oral cadre measurements used in this study. They are in accordance with Fain (1961) and Riley et al. (1990). All measurements are in micrometres unless otherwise stated. Where applicable, the mean is given, followed by the range in parentheses. Voucher specimens of the different genera have been deposited in the Helminthological Collection of Instituto Oswaldo Cruz, Rio de Janeiro (CHIOC).

\section{Data analyses}

For the purpose of this paper, the name 'Pentastomida' refers to the combined data of the three genera of Sebekidae and the single genus Subtriquetra of the Subtriquetridae found in this study; the use of the term pentastome(s) indicates that analyses were conducted for all three categories, Pentastomida, Sebekidae and Su. subtriquetra. A Chi-square test was used to determine the influence of host sex on the prevalence of pentastomes. Pentastome larvae showed an aggregated distribution and parasite counts were natural-log transformed $[\ln (\mathrm{x}+1)]$. Subsequently, pentastome counts were submitted to a two-way analysis of variance to assess the influence of host sex and collection month on mean abundance.

An additional three-factor analysis was used to compare monthly mean abundance between Sebekidae and Subtriquetra, adding family as a third factor. Shapiro-Wilk's test was performed on the residuals to test for deviation from normality (Shapiro and Wilk 1965). In order to compare the mean abundance of pentastome larvae during different collection months, Student's t-LSD (Least Significant Differences) was calculated at a 5\% significance level. Pearson correlation coefficients between fish weight, length and condition factor $\mathrm{k}$, respectively, versus the abundance of pentastomes were determined. All data 


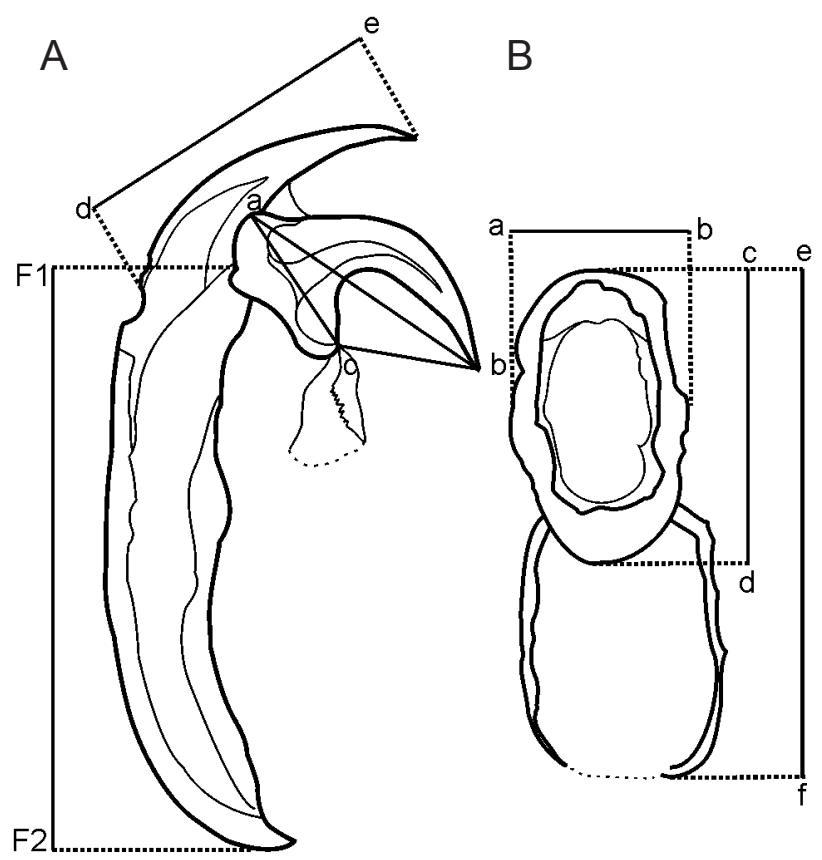

Fig. 1. Hook and oral cadre of infective larva of Sebekia sp., illustrating measurements used in this study. A - hook: hook length $(\mathrm{a}-\mathrm{b})$, base $(\mathrm{a}-\mathrm{c})$, gap of blade $(\mathrm{c}-\mathrm{b})$, accessory shield length (d-e), fulcrum length (F1-F2); B - oral cadre: width $(a-b)$, length $(c-d)$, overall length $(e-f)$.

were analysed using SAS version 9.2 statistical software (SAS 1999) and Excel 2010 with add-on software XLSTAT. The terms prevalence, (mean-) intensity of infection and (mean-) abundance are used in accordance with Bush et al. (1997).

The nomenclature and classification of fish follows that of Froese and Pauly (2013).

\section{RESULTS}

Infective pentastomid larvae recovered from Pygocentrus nattereri belonged to two families, Subtriquetridae and Sebekidae. The former was represented by a single species, Subtriquera subtriquetra, while members of the Sebekidae comprised the three genera Alofia Giglioli, 1922, Leiperia and Sebekia. Infective larvae of Su. subtriquetra were found free in the swim bladder of their hosts. Infective larvae of Alofia sp. were encysted in the abdominal cavity, chambers of the heart, the musculature, and on the surface of the gonads and swim bladder. Some specimens of Alofia sp. moved freely in the swim bladder. Larvae of Sebekia sp. were found encysted in the musculature. Encysted larvae of Leiperia sp. were seen in the musculature and on the surface of the pyloric caecae, whereas free-living larvae were collected from the abdominal cavity. With some of these, the head was buried deep in the wall of the intestine, stomach or ovaries, whereas the rest of the body was free in the abdominal cavity.

Infective pentastome larvae were present throughout the year; their prevalence and mean intensity of infection are listed in Table 1. A total of 1458 larvae was collected
Table 1. Pentastomid infection in male $(\mathrm{n}=76)$ and female $(\mathrm{n}=123)$ Pygocentrus nattereri Kner in Brazil.

\begin{tabular}{lcccc}
\hline Host sex & Prevalence (\%) & MA \pm SD & MI \pm SD & Range \\
\cline { 2 - 5 } & \multicolumn{5}{c}{ Pentastomida } \\
Males & 74 & $8.3 \pm 12.7$ & $8.6 \pm 10.7$ & $1-78$ \\
\hline Females & 79 & $6.7 \pm 10.1$ & $11.2 \pm 13.7$ & $1-69$ \\
Overall & 77 & $7.3 \pm 11.2$ & $9.5 \pm 11.9$ & $1-78$ \\
\hline \multicolumn{5}{c}{ Sebekidae } \\
Males & 70 & $7.5 \pm 12.4$ & $8.2 \pm 10.4$ & $1-75$ \\
\hline Females & 73 & $6.0 \pm 9.6$ & $10.8 \pm 13.6$ & $1-66$ \\
Overall & 72 & $6.6 \pm 10.8$ & $9.2 \pm 11.70$ & $1-75$ \\
\hline \multicolumn{5}{c}{ Subtriquetra subtriquetra } \\
Males & 32 & $0.8 \pm 1.7$ & $2.2 \pm 1.4$ & $1-12$ \\
\hline Females & 33 & $0.7 \pm 1.3$ & $2.4 \pm 2.3$ & $1-6$ \\
Overall & 33 & $0.7 \pm 1.5$ & $2.3 \pm 1.7$ & $1-12$ \\
\hline
\end{tabular}

MA - Mean abundance; MI - mean intensity; SD - standard deviation.

Table 2. Monthly mean abundance of pentastomids ( \pm standard deviation) in Pygocentrus nattereri Kner in Brazil, based on $\ln (x+1)$-transformed counts, with untransformed mean abundance in brackets.

\begin{tabular}{llll}
\hline Collection date & Pentastomida & Sebekidae & $\begin{array}{l}\text { Subtriquetra } \\
\text { subtriquetra }\end{array}$ \\
\hline April 2004 & $0.76 \pm 1.03$ & $0.76 \pm 1.03$ & $0.00 \pm 0.00$ \\
& $(3.0 \pm 5.9) \mathrm{b} *$ & $(3.0 \pm 5.9) \mathrm{cde}$ & $(0.0 \pm 0.0) \mathrm{c}$ \\
May 2004 & $0.75 \pm 0.82$ & $0.70 \pm 0.80$ & $0.09 \pm 0.32$ \\
& $(2.0 \pm 3.0) \mathrm{b}$ & $(1.8 \pm 3.0) \mathrm{de}$ & $(0.2 \pm 0.6) \mathrm{bc}$ \\
June 2004 & $0.92 \pm 1.30$ & $0.92 \pm 1.30$ & $0.08 \pm 0.22$ \\
& $(5.1 \pm 8.9) \mathrm{b}$ & $(5.0 \pm 8.6) \mathrm{bcde}$ & $(0.1 \pm 0.3) \mathrm{bc}$ \\
July 2004 & $0.67 \pm 0.80$ & $0.31 \pm 0.83$ & $0.36 \pm 0.46$ \\
& $(1.7 \pm 2.9) \mathrm{b}$ & $(1.1 \pm 3.0) \mathrm{e}$ & $(0.6 \pm 0.8) \mathrm{abc}$ \\
September 2004 $1.83 \pm 1.03$ & $1.74 \pm 1.03$ & $0.34 \pm 0.59$ \\
& $(9.7 \pm 14.8) \mathrm{a}$ & $(8.9 \pm 14.3) \mathrm{a}$ & $(0.8 \pm 2.0) \mathrm{abc}$ \\
October 2004 & $1.67 \pm 0.98$ & $1.44 \pm 1.08$ & $0.56 \pm 0.59$ \\
& $(8.1 \pm 13.6) \mathrm{a}$ & $(7.1 \pm 13.1) \mathrm{abc}$ & $(1.1 \pm 1.2) \mathrm{a}$ \\
November 2004 & $1.99 \pm 0.84$ & $1.78 \pm 0.91$ & $0.61 \pm 0.62$ \\
& $(8.9 \pm 7.8) \mathrm{a}$ & $(7.7 \pm 7.9) \mathrm{a}$ & $(1.2 \pm 1.4) \mathrm{a}$ \\
December 2004 & $1.75 \pm 1.09$ & $1.62 \pm 1.12$ & $0.44 \pm 0.61$ \\
& $(8.2 \pm 8.1) \mathrm{a}$ & $(7.3 \pm 7.7) \mathrm{ab}$ & $(0.9 \pm 1.4) \mathrm{ab}$ \\
January 2005 & $1.65 \pm 1.08$ & $1.39 \pm 1.15$ & $0.55 \pm 0.71$ \\
& $(7.8 \pm 9.7) \mathrm{a}$ & $(6.6 \pm 9.4) \mathrm{abcd}$ & $(1.3 \pm 1.9) \mathrm{a}$ \\
March 2005 & $1.97 \pm 1.07$ & $1.88 \pm 1.06$ & $0.47 \pm 0.62$ \\
& $(11.8 \pm 18.0) \mathrm{a}$ & $(10.9 \pm 17.3) \mathrm{a}$ & $(0.9 \pm 1.3) \mathrm{a}$ \\
\hline LSD (p=0.05) & 0.72 & 0.74 & 0.38 \\
\hline
\end{tabular}

LSD - Student's t-Least Significant Differences; * - means within each column with the same letter or letters do not differ significantly at the $5 \%$ level of significance.

from 199 P. nattereri and the majority of these belonged to the Sebekidae $(90 \% ; n=1309)$. No sex-related, statistically significant $(p>0.05)$ differences in prevalence or abundance were found. However, the overall prevalence (male and female hosts combined) of the Sebekidae was significantly higher than that of Su. subtriquetra (Chisquare 61.26; df $=1 ; \mathrm{p}<0.01)$. Similarly, a three-factor analysis of variance showed the overall mean abundance of the Sebekidae to be significantly higher $(\mathrm{p}<0.001)$ than that of Su. subtriquetra (untransformed: $6.6 \pm 10.8$ vs $0.7 \pm 1.5 ; \ln (\mathrm{x}+1)$-transformed: $1.4 \pm 1.1$ vs $0.4 \pm 0.6)$. 


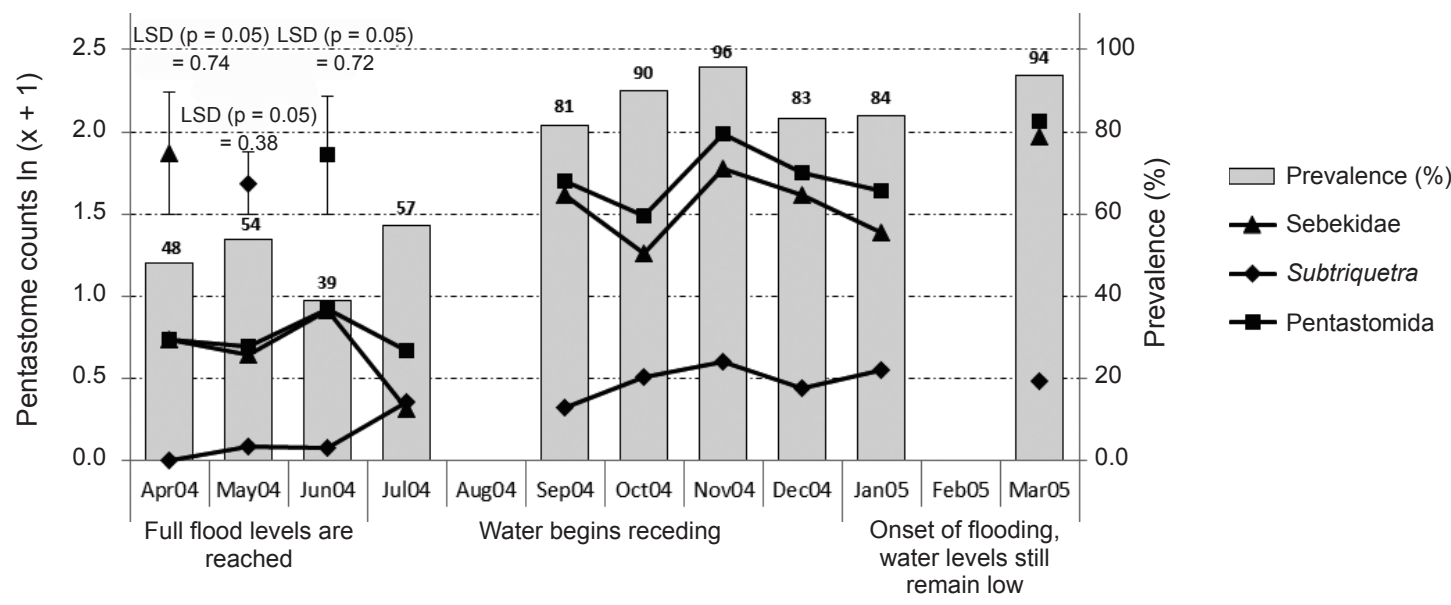

Fig. 2. Monthly prevalence of Pentastomida, and monthly mean abundance of pentastome larvae in Pygocentrus nattereri Kner $(n=199)$ in Brazil during the sampling period. LSD - Student's t-Least Significant Differences.

Fish ranged from 15 to $31 \mathrm{~cm}$ in length and weighed from 90 to $960 \mathrm{~g}$. Although significant positive correlations $(\mathrm{p}<0.05)$ were obtained between pentastome counts and fish weight $[\mathrm{r}=0.23-0.25$, untransformed; $\mathrm{r}=0.19-0.23$, $\ln (\mathrm{x}+1)$-transformed $]$ and length $[\mathrm{r}=0.16-0.27$, transformed; $r=0.19-0.25, \ln (x+1)$-transformed], respectively, these correlations were too low to be of any practical value, and significance was largely a result of the large number of hosts examined; this was true for both original and log-transformed counts. The abundance of pentastome larvae had no significant $(p \geq 0.22)$ influence on host condition ( $\mathrm{k}$ ).

Figure 2 illustrates the monthly prevalence and mean abundance of pentastome larvae during the collection period. A two-way analysis of variance (error degrees of freedom $\mathrm{df}=179$ ) showed a highly significant effect of sampling month on the mean abundance of pentastome larvae: Pentastomida $\left(\mathrm{MS}_{d f=9}=5.1 ; \mathrm{p}<0.0001\right)$; Sebekidae $\left(\mathrm{MS}_{d f=9}=4.46 ; \mathrm{p}=0.0002\right) ;$ Su. subtriquetra $\left(\mathrm{MS}_{d f=9}=0.95 ; \mathrm{p}=0.001\right)$. The overall prevalence for the period from April to July 2004 (47\%) was significantly lower than that for the sampling period from September 2004 to March 2005 (88\%) [Chi-square 30.38; df = 1; $\mathrm{p}<0.01]$. The monthly mean abundance of the Sebekidae, and to a lesser extent that of Su. subtriquetra, followed a similar trend (Fig. 2; Table 2). In September 2004, the Sebekidae had reached a significantly higher $(\mathrm{p}<0.05)$ mean abundance than in July 2004. Because the majority of pentastome larvae belonged to the Sebekidae, the trend of the Pentastomida followed this family closely.

\section{Description of infective larvae}

\section{Sebekia sp.}

Fig. 3

Description (Specimens deposited: CHIOC 37813 and 37814): Based on nine male specimens unless otherwise stated. All specimens ruptured between rows of spines $10-23$, in region of protruding copulatory spicules.
Copulatory spicules at an early stage of maturation, genital organs not fully formed yet. Gonopore opening on first annulus, conspicuous. Live specimens off-white in colour, 2.6 (2.1-3.3) mm long, 0.8 (0.6-0.9) $\mathrm{mm}$ wide; abdomen tapering posteriorly. Oral cadre closed anteriorly, oval in shape, $64(58-72, \mathrm{n}=8)$ wide, cadre length $115(96-132)$, overall length 178 (143-216). Hooks double, convex dorsally, slender and slightly curved; anterior hook length 81 (62-91), base 47 (43-52), gap of blade 38 (28-52); posterior hook length 82 (69-93), base 50 (45-60), gap of blade 37 (33-43); accessory shields robust and slightly curved, anterior shield 90 (76-108) long, posterior shield 84 (69-96) long; fulcra long and slender, anterior fulcrum length 167 (143-201), posterior fulcrum length 168 (144-199). Annuli numbering 65 (60-76), including first two incomplete rows of spines. Spines large, 24 (24-24) in overall length. Chloride cell pores large, arranged in single row at anterior border of each annulus.

Remarks. All larvae have the double hooks and rows of annular spines typical for infective larvae of the family Sebekidae (Winch and Riley 1986a). The shape of the oral cadre differentiates these specimens from those of the genus Alofia, in which the cadre is open anteriorly, has more or less parallel sides, giving it a U-shaped appearance, and a peg-like extension into the oesophagus (Riley 1994). The oral cadre of infective larvae and adults of Leiperia is pitted with numerous canals (Riley and Huchzermeyer 1996). Such canals were absent in the present specimens. The only other sebekiid genus known from South American hosts is the monotypic genus Diesingia Sambon, 1922. Adult D. megastoma possess an extraordinarily large oral cadre that by far exceeds the size of the hooks, including their fulcra (Junker et al. 2003), a criterion one would expect to be reflected in its infective larva.

Presently, three species of Sebekia have been recorded from South American crocodilians: S. trinitatis Riley, Spratt et Winch, 1990 from Ca. crocodilus (syn. Ca. scle- 

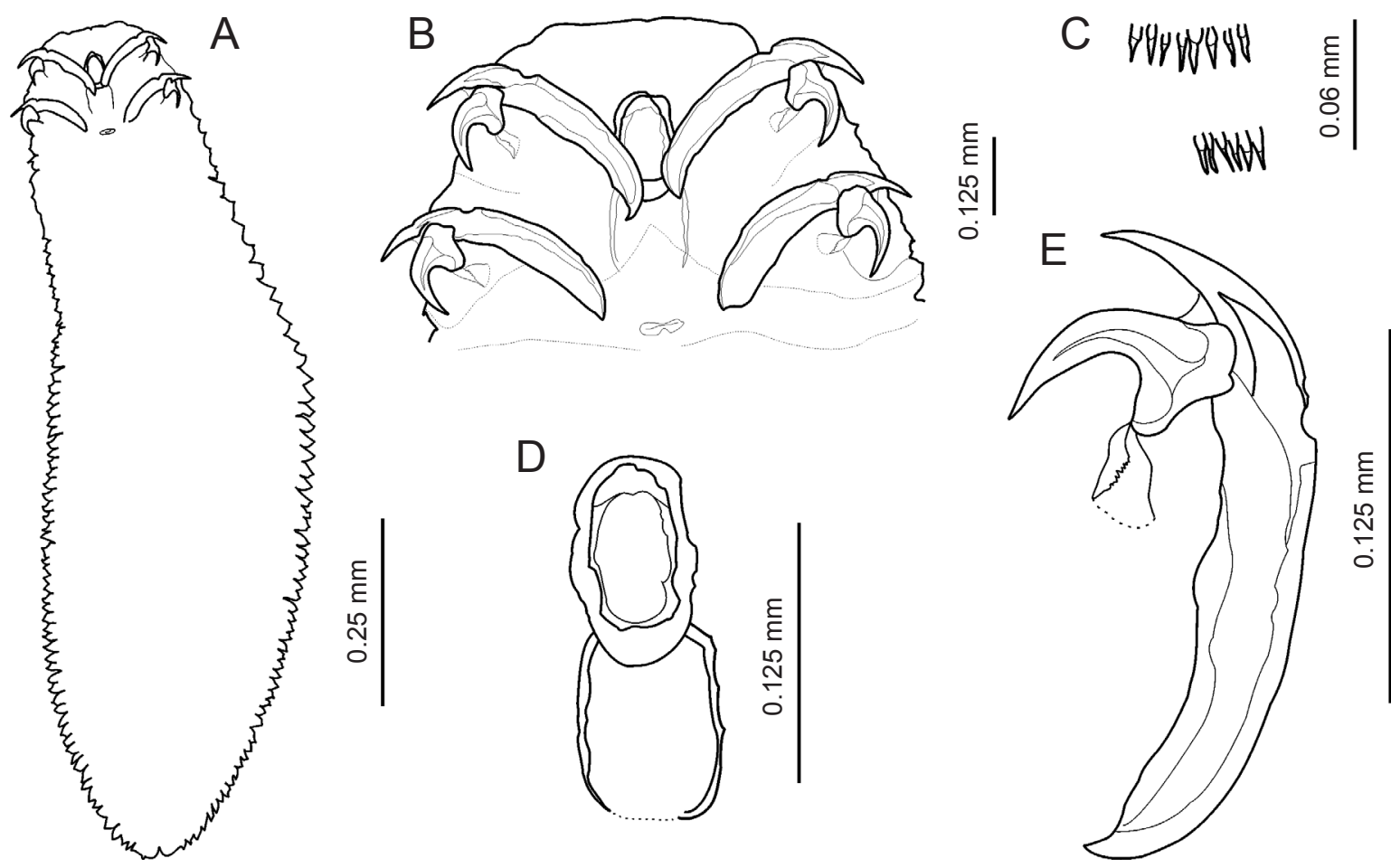

Fig. 3. Sebekia sp. A - infective larva; B - head in ventral view, showing oral cadre between anterior pair of hooks, and gonopore on the first annulus; $\mathbf{C}$ - small patch of spines; $\mathbf{D}$ - oral cadre, closed anteriorly; $\mathbf{E}$ - anterior hook with accessory shield.

rops) in Trinidad, S. divestei Giglioli in Sambon, 1922 from Crocodylus acutus (Cuvier) (Crocodylidae) from an unknown locality, and $S$. oxycephala from $C$ a. crocodilus (syn. Ca. sclerops) and Cr. acutus in South and Central America (Sambon 1922, Riley et al. 1990). Riley et al. (1990) consider $S$. oxycephala a species inquirenda.

Whereas the shape of the oral cadre of the current specimens and the large spines on the posterior margin of each annulus are reminiscent of adults and infective larvae of S. trinitatis (see Riley et al. 1990), S. trinitatis has a lower annulus count (54-62 vs 60-76). In addition, Riley et al. (1990) report a single row of chloride cells on the posterior half of each annulus in infective larvae, whereas chloride cells are arranged on the anterior margin of each annulus in our specimens. Hook length in infective larvae of $S$. trinitatis is slightly longer than that seen in the present specimens (85-108 vs 62-93). A single infective larva of $S$. divestei differs from the present specimens in the arrangement of chloride cells in 2-3 rows per annlus, a row of minute spines per annulus and slightly longer hooks (108 vs 62-93) (Riley et al. 1990).

Infective larvae described as $S$. oxycephala by Winch and Riley (1986a) possess fewer annuli (56-58) and a single row of spines in the mid-annulus region. Their hook length $(75-90 \mu \mathrm{m})$ as well as oral cadre length (103-126 $\mu \mathrm{m})$ does, however, fall within the range of the present specimens. Based on the available, scant information, and taking into account that intraspecific variation can be considerable in pentastomids (Riley and
Huchzermeyer 1995a), we cannot assign our specimens to either of the species of Sebekia currently described from South American hosts.

\section{Leiperia sp.}

Fig. 4

Description (based on ten unsexed specimens unless otherwise stated; specimens deposited: CHIOC 35812a,b): Live larvae off-white in colour. Body elongated, slender in appearance, 20.9 (17.3-25.1) mm long, 1.0 (0.8-1.1) mm wide. Oral cadre open anteriorly, V-shaped, with broad anterior flanges, located between anterior hooks, permeated with pores, $138(127-150, \mathrm{n}=7)$ wide, cadre length $310(230-370, \mathrm{n}=9)$, overall length 440 (360-500). Hooks large, with strongly recurved blade, overlain by curved, accessory shield: anterior hook length 254 (230-270), base 138 (120-168), gap of blade 111 (84-127); posterior hook length 269 (230-297), base 142 (108-160), gap of blade 118 (108-127); anterior shield 255 (230-280) long, posterior shield 286 (260-310) long; anterior fulcrum length 579 (400-650), posterior fulcrum length 582 (480-653). Annuli numbering 106 (98-120), including incomplete rows of spines. Spines $12(12, n=1)$ in overall length, fringed with small spines. Chloride cell pores disposed in irregular rows 5-7 deep, spread over entire annulus anteriorly, reduced to 3-4 deep posteriorly; chloride cell pores more numerous on dorsal than on ventral surface.

Remarks. The present specimens display numerous characteristics typical of the genus Leiperia including 

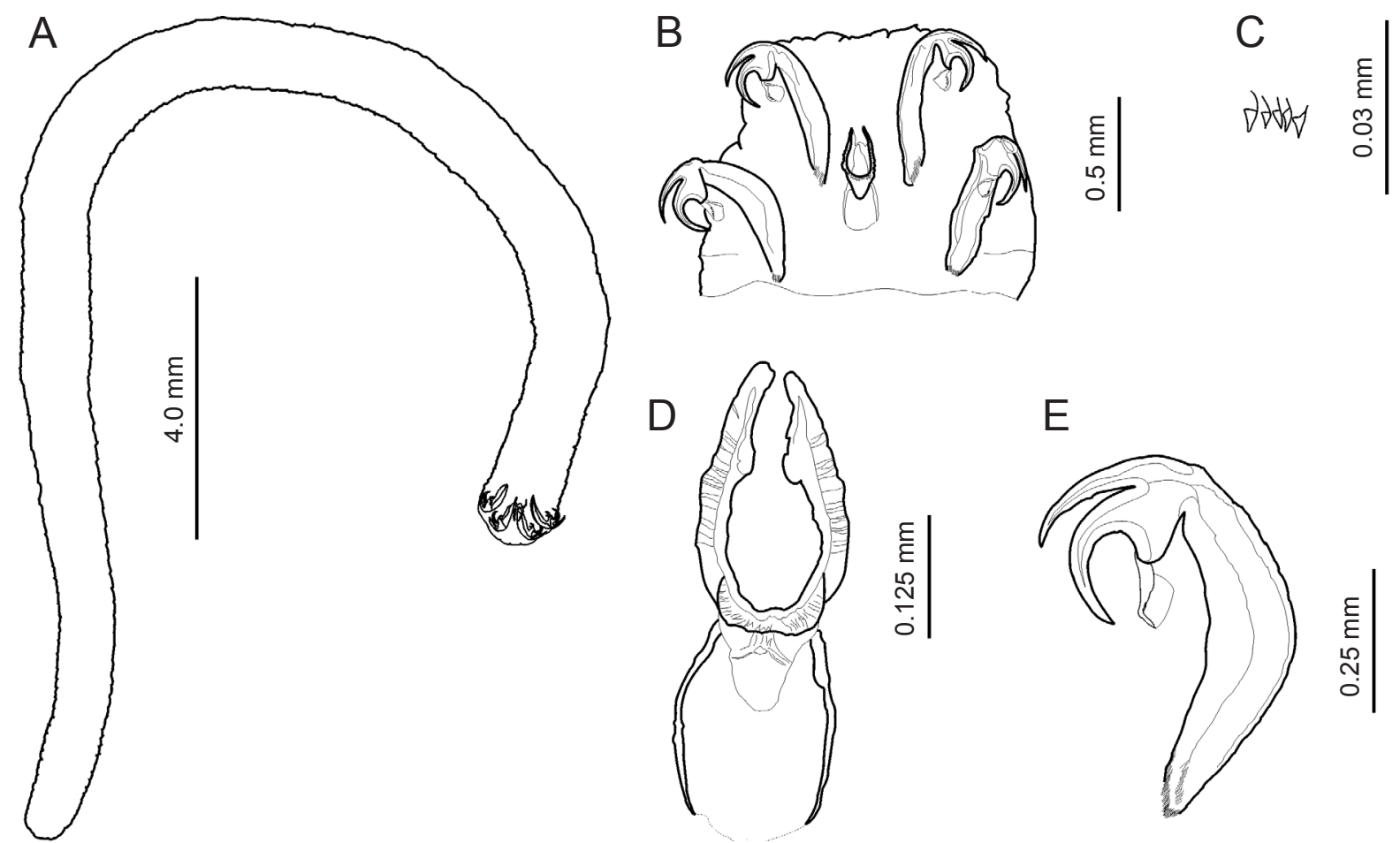

Fig. 4. Leiperia sp. A - infective larva; $\mathbf{B}$ - head in ventral view, showing oral cadre between anterior hooks; $\mathbf{C}-$ small patch of minute spines; D - oral cadre, open anteriorly, V-shaped, permeated by numerous fine canals; $\mathbf{E}$ - anterior hook, strongly recurved, with accessory shield.

their size, number of annuli, the V-shaped oral cadre permeated by pores, large hooks and the disposition of chloride cells in several irregular rows across the entire annulus (Sambon 1922, Riley and Huchzermeyer 1996, Junker et al. 2000). Worldwide, two species of Leiperia are currently well-described and considered valid: L. cincinnalis Sambon, 1922 parasitising Cr. niloticus Laurenti in Africa, and L. australiensis Riley et Huchzermeyer, 1996 from Cr. porosus Schneider and Cr. johnstoni Krefft in Australia (Sambon 1922, Heymons and Vitzthum 1936, Heymons 1940a, b, Riley and Huchzermeyer 1996, Junker et al. 2000).

Much confusion does, however, surround the status of this genus in South America. Diesing $(1836,1850)$, described and listed pentastomid specimens that had been collected from a large number of mainly amphibian and fish hosts by J. Natterer in Brazil during 1824-1827 and named them 'Pentastoma gracile'. Since then, several authors have partially re-examined and redescribed material originating from this collection or have described specimens from yet other hosts under either this binomial or, later, as 'Leiperia gracilis' (see Leuckart 1860, Heymons and Vitzthum 1936, Heymons 1940a; for a detailed review of the literature see Riley and Huchzermeyer 1996). Based on the various descriptions and host data, the latter authors concluded that Leiperia is in all likelihood represented by two species in South America, presently known as nymphs only, and that L. gracilis should be considered a species inquirenda.
Comparison of the morphological characters of the present South American specimens with those of infective larvae of $L$. cincinnalis and $L$. australiensis reveals few differences. This corresponds with Riley and Huchzermeyer's (1996) observation that infective larvae of the African and Australian species are very similar, and that even differences between adult females are subtle. The disposition of chloride cell pore caps in the present specimens is typical for species of Leiperia in that they are spread over the entire annulus, but particular in so far as they are 5-7 cells deep anteriorly, while being reduced to 3-4 deep posteriorly. In addition, chloride cell pores seemed more numerous on the dorsal than on the ventral surface. This, as well as rows that are 5-7 deep, are characters shared with females of $L$. australiensis; no data are available on the infective larvae of this species (Riley and Huchzermeyer 1996).

When looking at a combination of the characters body length, number of annuli and disposition of chloride cell pores, the following South American infective larvae described in the literature resemble the present specimens of Leiperia: (i) Pentastomum gracile sensu Parona, 1890 (19 $\mathrm{mm}$ long, chloride cells in rows 5-6 deep) from Hophias malabaricus [syn. Macrodon trahira (Spix)] (see Sambon 1922); (ii) two large specimens (105 annuli, <25 mm long) in a collection of specimens from Cr. acutus (syn. Cr. americanus Laurenti) in Ecuador, identified by W.M. Wheeler as 'Porocephalus crocodile' (see Heymons and Vitzthum 1936, Heymons 1940a, Riley and Huchzermey- 

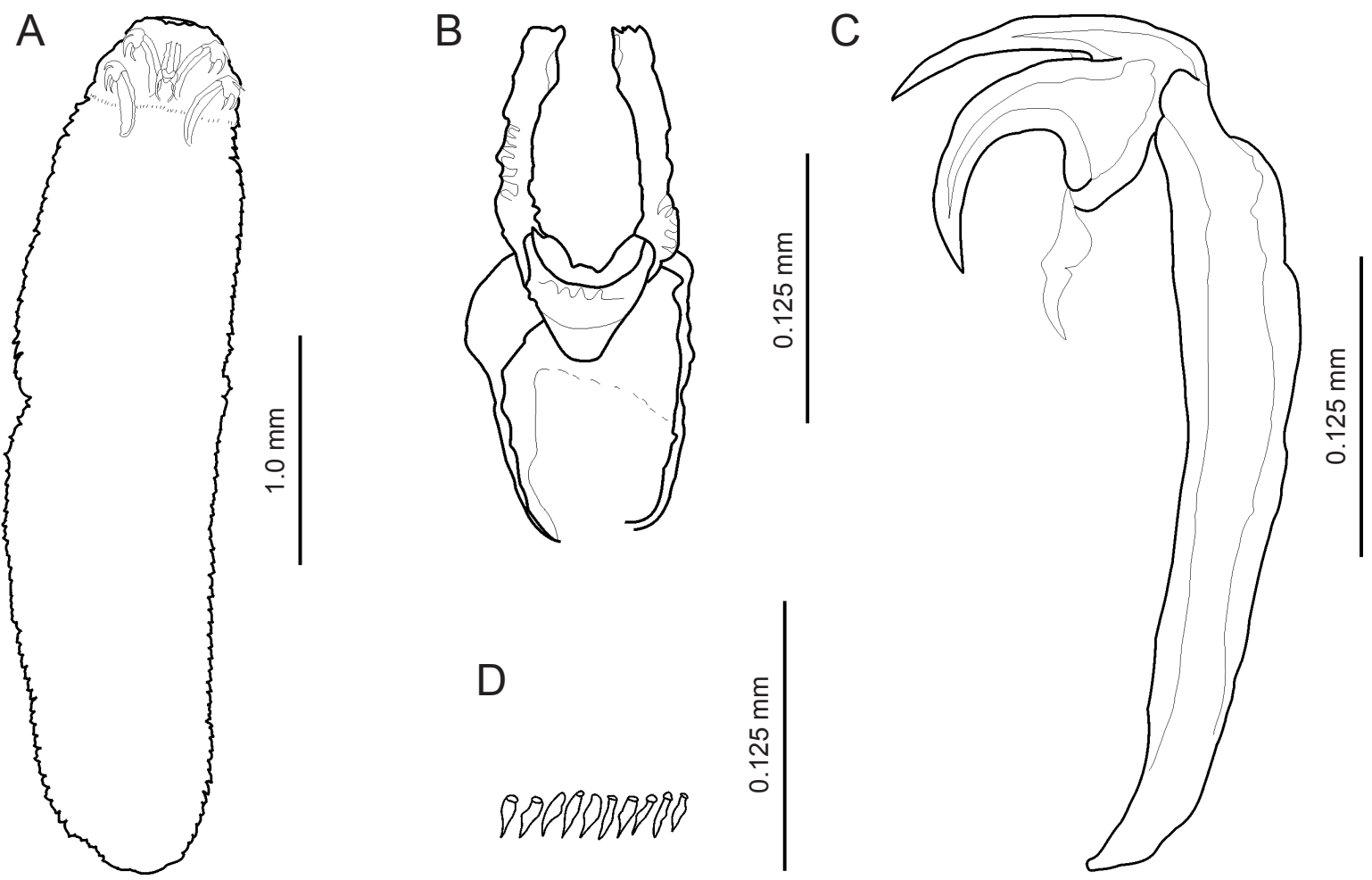

Fig. 5. Alofia sp. A - infective larva; B - oral cadre, open anteriorly, U-shaped, with parallel sides, situated between anterior hooks; $\mathbf{C}-$ anterior hook with accessory shield; $\mathbf{D}$ - small patch of spines.

er 1996); (iii) specimens identified as 'large species A' by Heymons and Vitzthum (1936), when re-examining some of Diesing's material from various hosts (105 annuli, mostly 18-22 mm long, chloride cells in rows 5-7 deep); (iv) an infective larva from Gobioides peruanus (Steindachner) (Gobiidae), Ecuador, initially described as 'Leiperia neotropica', but later identified as belonging to the 'large species A' by Heymons and Vitzthum (1936).

Heymons and Vitzthum (1936) concluded that the above specimens (i-iv) all belonged to Pentastomum gracile sensu Leuckart, 1860, who had assigned this name to specimens from $S$. brasiliensis [syns. S. brevidens and Hydrocyon brevidens (Cuvier)], exclusively and which were characterised by rows of pores four to five deep, had \pm 90 annuli and were $11 \mathrm{~mm}$ long (Sambon 1922, Heymons and Vitzthum 1936).

We agree with Riley and Huchzermeyer (1996) that the status of L. gracilis is doubtful and that the genus might well be represented by more than a single species in South America. Hence, we cannot give a specific diagnosis for our specimens, but designate them as Leiperia sp. until such time the questions surrounding this genus in Neotropical hosts can be addressed.

\section{Alofia sp.}

Fig. 5

Description (based on nine specimens unless otherwise stated; specimens deposited: CHIOC 37810 and 37811): Live larvae off-white in colour. Body 6.6 (4.0-9.0) mm long, $0.8(0.7-1.0) \mathrm{mm}$ wide. Oral cadre open anteriorly, with peg-like extension into oesophagus and nearly parallel sides; $76(67-88, \mathrm{n}=8)$ wide, cadre length 165 (136-180), overall length 251 (204-273). Hooks convex dorsally and with accessory shield; anterior hook length 116 (76-132), base 67 (55-81), gap of blade 49 (36-57); posterior hook length 125 (100-139), base 72 (60-84), gap of blade 53 (45-60); anterior shield 112 (84-124) long, posterior shield 107 (76-132) long; anterior fulcrum length 289 (192-331), posterior fulcrum 304 (168-336) long. Annuli numbering 63 (60-65); irregular rows of chloride cell pores on posterior half of each annulus, 1-3 deep. Overall length of spines 23 (19-26).

Remarks. Based on the shape of the oral cadre, which is open anteriorly, has nearly parallel sides, a peg-like extension into the oesophagus and is situated between the two anterior hooks rather than being placed between the anterior and posterior pairs of hooks, the current material is assigned to Alofia (see Riley 1994 for generic diagnosis). Furthermore, when compared to Sebekia, the hooks are longer, the fulcrum is longer, more slender and comparatively straight, and the dimensions of the oral cadre are larger (Riley et al. 1990, Riley 1994).

Heymons and Vitzthum (1936) examined approximately 80 specimens that had been collected by J. Natterer from two male $\mathrm{Ca}$. crocodilus from Rio Cabaçal, Brazil in 1825 and that had subsequently been placed into a single vial labelled 'Pentastomum oxycephalum' by K.M. Diesing. They concluded that the collection comprised two morphologically similar species and that the majority of 
specimens should be assigned to what Lohrmann (1889) had described as 'Pentastomum platycephalum' and which was then known as $A$. platycephala. According to Heymons and Vitzthum (1936), all specimens were mature females, but later Heymons (1941) stated that both mature males and females were present. The specimens possessed the following characteristics: body cylindrical, often with posterior swelling, reaching $22 \mathrm{~mm}$ in length, about 70-80 annuli; hook blade sharply bent above base; oral cadre weakly chitinized anteriorly, giving it an open, U-shaped appearance, positioned between the anterior pair of hooks (Heymons and Vitzthum 1936).

While it is difficult to compare infective larvae with their adult counterparts, certain characters that are diagnostic in adults can be recognized in the infective larvae; in porocephalids, the final number of annuli is reached in the infective stage and the oral cadre bears a strong resemblance to that of the adult (Winch and Riley 1986a, Junker et al. 1998a). Heymons (1941) illustrates the anterior part of a mature male of $A$. platycephala from Ca. latirostris (Daudin) from Paraguay, which resembles our infective larvae in a number of characters: the oral cadre is U-shaped, elongated, with a long pharynx and is positioned between the two anterior hooks. Furthermore, the long and slender shape of the fulcra is similar.

It is noteworthy that the chloride cell pores in the present specimens are distributed in several rows of 1-3 cells in the posterior half of each annulus. The only other currently known species of Sebekia with more than a single row of chloride cell pores per annulus are $S$. okavangoensis Riley et Huchzermeyer, 1995 from Cr. niloticus, Cr. cataphractus Cuvier and Osteolaemus tetraspis Cope in Africa (Riley and Huchzermeyer 1995a,b, 2000), known only as adults, and $S$. divestei from $C r$. acutus from an unknown locality (Riley et al. 1990). Chloride cell pores were arranged in 2-3 rows per annulus in a single infective larva of $S$. divestei. Their disposition in adults was not ascertained; males are unknown and it remained undetermined in two fragmented females (Riley et al. 1990). The oral cadre of adult $S$. divestei as illustrated in Sambon (1922) is closed anteriorly, has convex sides and shows little similarity with that seen in our specimens.

Riley (1994) in his revision of the genus Alofia presented diagnostic criteria of $A$. platycephala from $C a$. crocodilus in Brazil and from $\mathrm{Ca}$. latirostris in Paraguay compiled from Shipley (1898), Heymons (1941) and Self and Rego (1985), but these exclusively refer to adult specimens and information on infective larvae is not available. Self and Rego (1985) suggested that A. platycephala was synonymous with $A$. merki Giglioli, 1922. Riley (1994) did not support this hypothesis, however, and speculated that $A$. merki was most probably parasitic in $C r$. porosus. Thus, A. platycephala is presently the only recognised species of Alofia in South America. However, in the absence of data on the infective larvae of this species and given the slight deviation in the number of an- nuli between our specimens and adults of $A$. platycephala (60-65 vs 70-80) (Shipley 1898, Heymons 1941), rather than assigning our specimen to this taxon, we list them as Alofia sp.

\section{Subtriquetra subtriquetra}

Fig. 6

Description (based on 15 specimens; material deposited: CHIOC 37815a,b): Body elliptical, 2.8 (2.3-3.7) mm long, 0.9 (0.8-1.1) mm wide; ventrally flattened and dorsally convex; some red in colour, others white. Oral cadre closed anteriorly, situated between anterior pair of hooks; width 105 (81-120), cadre length 166 (117-199), overall length 196 (142-228). Hooks simple, blades sharply bent and pointed; anterior hook length 244 (186-304), base 115 (96-127), gap of blade 114 (74-132); posterior hook length 237 (177-292), base 117 (100-129), gap of blade 107 (67-124). Fulcra long and curved; anterior fulcrum 388 (299-496) in length, posterior fulcrum 367 (269-410) long. Conspicuous rows of sharply pointed spines, 31 (24-36) long, on each annulus. Annuli numbering 31 (29-33), including incomplete rows of spines in the ventral anterior region. Chloride cell pores disposed in single row at anterior border of each annulus.

Remarks. Subtriquetra subtriquetra is presently the only species of the genus described from the nasopharynx of South American crocodilians (Sambon 1922, Winch and Riley 1986b), whereas another three species have been recorded from India and Africa. Subtriquetra megacephala (Baird, 1853) and Subtriquetra shipleyi (Hett, 1924) have been described from Indian crocodiles (Sambon 1922), and the description of Subtriquetra rileyi Junker, Boomker et Booyse, 1998 is based on infective larvae recovered from cichlids in Africa (Junker et al. 1998a). The immature stages of Su. subtriquetra are known to occur free in the swim bladder of a number of fish, where they undergo seven moults. Hooks are retained throughout the development; those of earlier larvae are distinctly doubled, but the outer blade is gradually reduced during larval development. Hooks are rudimentary in the sixth instar and absent in the final two larval stages (Winch and Riley 1986b).

The hooks of the present specimens from $P$. nattereri carry no remnants of an outer blade, and, thus, represent either the seventh or eighth instar of Su. subtriquetra. Mean measurements correspond well with those provided by Winch and Riley (1986b) for the eighth instar, but because of the wide range present in our measurements, we cannot exclude that some seventh instars were present as well. In addition, a total annulus count of 31 (29-33), including incomplete rows, places our larvae well within the range of 31-34 of the last two larval stages of $S u$. subtriquetra from Aequidens pulcher (Gill) (Cichlidae) in Trinidad (Winch and Riley 1986b). Given the fact that the present specimens do not only originate from a different host, but also from a different geographic area, a certain degree of variation could be expected. No significant 

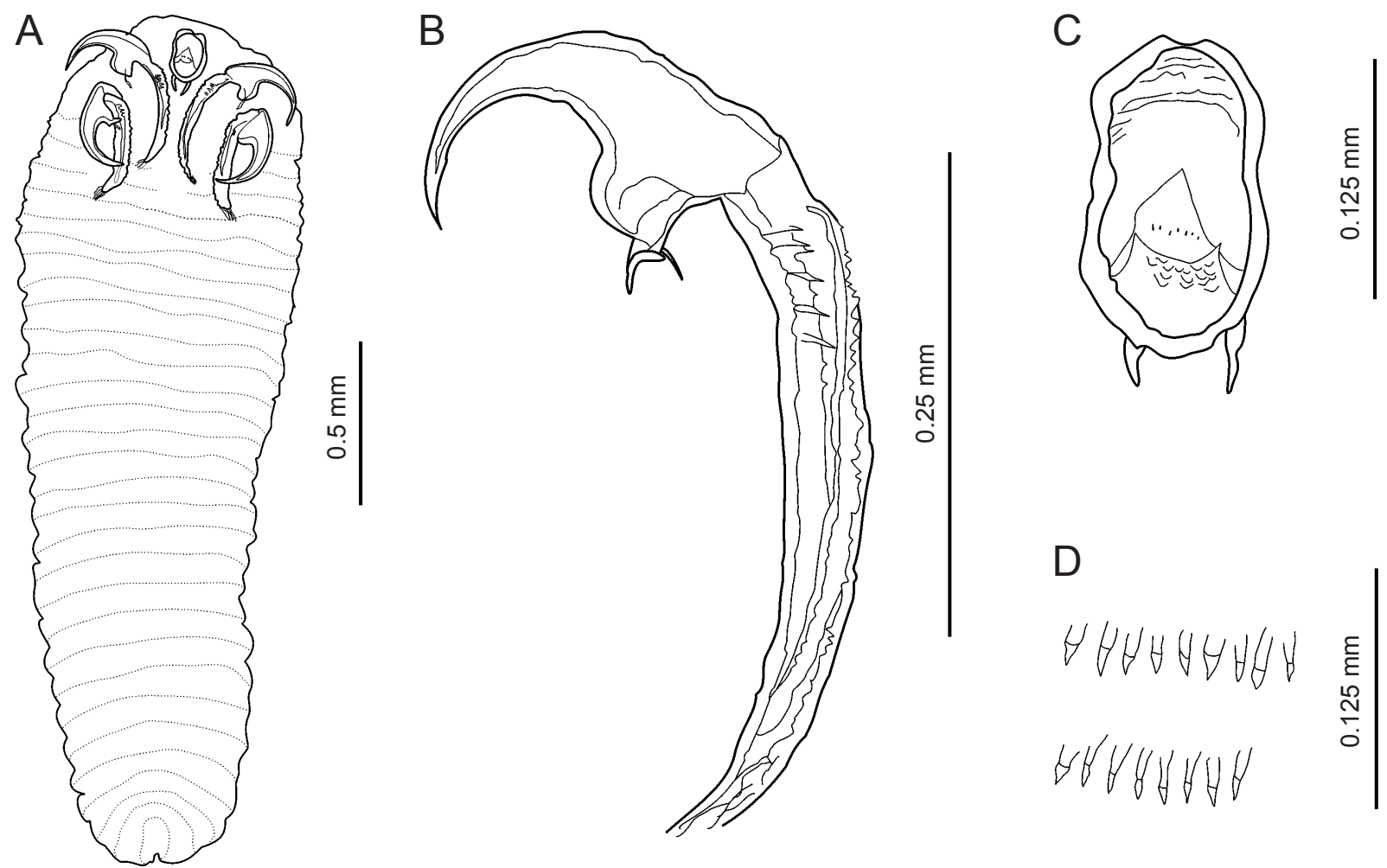

Fig. 6. Subtriquetra subtriquetra. A - infective larva; B - anterior hook without accessory shield; C - oral cadre, closed anteriorly; D - small patch of spines.

discrepancies between our specimens and the infective larvae of Su. subtriquetra described by Winch and Riley (1986b) were obvious.

\section{DISCUSSION}

Despite the fact that pentastomids are potentially important endoparasites of tropical and subtropical fish, information on this particular host-parasite association in the literature is scant (Sambon 1922, Fain 1961, Boyce 1985, Boyce et al. 1987, Winch and Riley 1986a,b, Junker et al. 1998a, Barros et al. 2010). To our knowledge, the finding of Subtriquetra subtriquetra, Alofia sp. and Leiperia sp. in Pygocentrus nattereri represents new parasitehost records, and infective larvae of a species of Alofia have been reported for the first time from Brazil.

Our current findings support the conclusion of Winch and Riley (1986b) that, while pentastomids in general exhibit degrees of site selection, that of Subtriquetra spp. is the most restricted of all. As in previous studies on both Su. subtriquetra and Su. rileyi, infective larvae of Su. subtriquetra in P. nattereri were found exclusively in the swim bladder (Winch and Riley 1986b, Junker et al. 1998a, Luus-Powell et al. 2008). Contrary to this, infective larvae of the Sebekidae have been reported from the swim bladder as well as from the body cavity of fish.

Larvae of Sebekia mississippiensis Overstreet, Self et Vliet, 1985 were found under the connective tissues lining muscle, kidney, liver, swim bladder and the gastrointesti- nal tract as well as attached to the abdominal wall (Overstreet et al. 1985, Boyce et al. 1987). Encysted as well as free-living infective larvae of Sebekia wedli Giglioli, 1922 occurred in the swim bladder of the two cichlids Tilapia rendalli (Boulanger) and Oreochromis mossambicus (Peters) in South Africa, and Leiperia cincinnalis was encysted on the mesenteries of both these fish (Junker et al. 1998b). Similar to $S$. wedli, some Alofia larvae were free in the swim bladder of $P$. nattereri, and specimens of all three genera were recovered from cysts in the musculature and the surface of a number of organs.

Data on the epidemiology of Subtriquetra spp. in fish are scant. The overall prevalence of $33 \%$ of Su. subtriquetra in P. nattereri in Brazil is almost twice that of infective larvae of Su. subtriquetra in Aequidens pulcher in Trinidad $(18 \%, \mathrm{n}=99)$, but intensities in both hosts were similar, ranging from 1-12 in P. nattereri and from 1-7 in A. pulcher (see Winch and Riley 1986b). In South Africa, the prevalence of Su. rileyi in T. rendalli and O. mossambicus, was $2 \%(\mathrm{n}=185)$ and $8 \%(\mathrm{n}=119)$, respectively. Fish usually harboured a single infective larva only, with a maximum of two in O. mossambicus (Junker et al. 1998a). Luus-Powell et al. (2008) found similarly low prevalences (maximum 6\%) and intensities (1-6) of $\mathrm{Su}$. rileyi in $O$. mossambicus.

The prevalence and intensity of the Sebekidae varies in different hosts. Contrary to the high prevalence and relatively high intensities seen in the Sebekidae in 
$P$. nattereri in the current study, the prevalence of $S$. oxycephala in A. pulcher in Trinidad was 4\% $(\mathrm{n}=98)$ and in Tilapia sp. 2\% $(\mathrm{n}=65)$ (Winch and Riley 1986b). Each of these hosts carried a single infective larva only. The prevalence of $S$. mississippiensis in 24 Gambusia affinis (Baird et Girard) (Poeciliidae) from a man-made lake in Florida was comparatively high with $58 \%$ and a mean intensity of infection of 4.8 (Ferenc et al. 1986). On three occasions, Boyce (1985) found the prevalence of $S$. mississippiensis in the same host species at the same locality to be 60,72 and $86 \%$, respectively, with a mean intensity of 9.1 (1-28), 4.5 (1-51) and 9.9 (1-79). The latter findings compare well with the prevalence and intensity of the Sebekidae in the present study. Both prevalence and intensity of S.wedli from South African hosts were lower, $41 \%$ with a mean intensity of $1.8(1-8)$ in $T$. rendalli and $3 \%$ with a mean intensity of $3.7(1-8)$ in $O$. mossambicus (see Junker et al. 1998a).

Neither in the present nor in previous studies did infections with species of Subtriquetra exceed 12 infective larvae per host (Winch and Riley 1986b, Junker et al. 1998a, Luus-Powell et al. 2008), whereas up to 79 infective larvae per fish have been reported for sebekiids (Boyce 1985). Two possible causes for the persistently low intensities of Subtriquetra spp. come to mind. Contrary to the infective larvae of the Sebekidae, which become enclosed in a cyst of host origin, subtriquetrids remain mobile and continue to suck blood, as evidenced by feeding marks in the wall of the swim bladder of infected hosts (Junker et al. 1998a). Thus, they remain exposed to the host's immune response throughout their development and the majority of developing subtriquetrids might eventually be killed.

More probable, however, is that their continued mobility and feeding activity, associated with constant irritation and damage of host tissues as well as blood loss, render them more pathogenic than their encysted counterparts. Hence, fish might only be able to tolerate low intensities of Subtriquetra spp. before succumbing to infection. According to Riley (1986), Su. subtriquetra larvae are highly pathogenic in small fish, killing experimentally infected Poecilia latipinna (Lesueur) (Poeciliidae) when larvae attain a length of $0.8 \mathrm{~mm}$, and the majority of fish infected with two larvae died when these reached third or fourth stage (Winch and Riley 1986b).

Contrary to this, mature infective porocephalid larvae did not elicit any inflammatory response in both reptile and mammal intermediate hosts (Self and Kuntz 1967), suggesting a high compatibility between pentastomid parasites and hosts with a long history of co-evolution (Riley 1986). Boyce et al. (1987) found S. mississippiensis to affect different fish species differently. While developing larvae were associated with a mild inflammatory response in G. affinis, they caused extensive traumatic damage and prominent lesions in Xiphophorus helleri (Heckel) (Poeciliidae), even though intensities in this host were ob- served to be lower. We could find no significant correlation between intensity of infection and host condition. In the case of the Sebekidae, we believe this indicates a low pathogenicity and a well-established host-parasite association, whereas in the case of Su. subtriquetra we assume that hosts, in which the tolerable number of parasites is exceeded, die fast and are thus removed from the host pool.

The particular mode of transmission of subtriquetrids might have an even greater impact on their ability to infect large numbers of hosts when compared to the Sebekidae. Free-living primary larvae of Su. subtriquetra have been shown to survive for up to six days, but their ability to successfully penetrate the skin of a host dropped rapidly after two days (Winch and Riley 1986b). A stationary fishing posture was adopted between brief periods of movement; however, movement was not directed towards any offered stimuli and largely stopped after two days, indicating that attachment to a fish depended on a chance physical contact (Winch and Riley 1986b). Clearly the likelihood of such a random encounter would increase with the density of available fish hosts.

Pygocentrus nattereri lives in schools from up to 20 to 30 individuals (Sazima and Machado 1990). Carvalho et al. (2003) took this gregarious behaviour of $P$. nattereri to be the reason for the higher intensity of branchiuran ectoparasites when compared to the characids Serrasalmus spilopleura Kner, which lives in smaller groups, and Se. marginatus Valenciennes, a solitary species. Similarly, Tanaka (2000) concluded that group-living versus being solitary was the main factor in determining ectoparasite communities of Se. spilopleura and Se. marginatus. In the present study, the prevalence of Su. subtriquetra in gregarious $P$. nattereri $(33 \%)$ was considerably higher than that found in solitary living cichlids from Trinidad and South Africa, where it reached $18 \%$ and $8 \%$, respectively (Winch and Riley 1986b, Junker et al. 1998a).

A further behavioural trait of $P$. nattereri that might influence prevalence and intensity of infection with both species of the Sebekidae and Subtriquetra is their preying on other fish. The question arises if smaller fish species, while being suitable intermediate hosts themselves, could also serve as transport hosts, increasing the likelihood of exposure of predatory fish to pentastomid parasites. This assumption is supported by observations of Winch and Riley (1986b): Su. subtriquetra larvae taken from the swim bladder of experimentally infected fish were able to invade new hosts and to enter their swim bladder seven days post-infection. Thus, infective or developing pentastomid larvae ingested by $P$. nattereri when preying on infected fish might survive and/or continue their development in the new host.

A weak positive correlation was seen between both fish weight and length and counts of pentastome larvae. Guégan and Hugueny (1994) attributed the greater species richness seen in larger/older specimens of Labeo coubie Rüppell, a West African cyprinid, to their longer 
availability for random parasite colonisation, as well as the availability of more niches for parasite colonisation in larger fish. Infective pentastomid larvae can survive in their host for many years (Riley 1986), and it is thus likely that the high intensities of the Sebekidae seen in some of the hosts herein are the accumulative result of number of subsequent infections. Contrary to the longevity of infective larvae, the various developmental stages of pentastomid larvae do not persist long, and the infective stage is reached within weeks (Winch and Riley 1986a,b, Junker et al. 1998b). This might well explain why infective larvae were the only or most prevalent developmental stage recovered in the present as well as in previous studies ( $\mathrm{Ri}$ ley 1986, Junker et al. 1998a).

Seasonal hydrological changes in the study area had a significant effect on the prevalence and abundance of pentastomid parasites in $P$. nattereri. Abundance of the Sebekidae was lowest during the flooding season (April to June 2004) and increased gradually to a maximum in March 2005, the last month of the season called 'dryflooding', during which flooding begins, but water levels still remain low. A similar phenomenon was described for branchiuran parasites of Se. marginatus, Se. spilopleura and P. nattereri by Carvalho et al. (2003). These authors found the highest ectoparasite burdens during the dry-flooding season and ascribed this to the progressive increase in host population densities as water levels drop to a minimum, as well as to host stress, due to a reduction in food availability and deterioration of water quality. Receding water levels force aquatic hosts to concentrate in smaller areas, thus creating ideal conditions for host exposure to both large numbers of sebekiid eggs or subtriquetrid primary larvae.

Acknowledgments. We thank A. Flávio Giesen, who collected the fish, and Berenice L. Pereira and Edinéia dos Santos for their assistance with parasite recovery. The Universidade Federal de Mato Grosso do Sul (UFMS) is acknowledged for help with logistics at the Base de Estudos do Pantanal (BEP). Further thanks go to Prof. Hélder S. e Luna (UFMS) and our colleagues at the Laboratório of the Universidade Estadual de Maringá, as well as to Prof. Jean Christophe Joyeux at the Universidade Federal do Espírito Santo. The Instituto Oswaldo Cruz (IOC) assisted with the loan of slides.

\section{REFERENCES}

Almeida W.O., Christofferson M.L. 1999: A cladistic approach to relationships in Pentastomida. J. Parasitol. 85: 695-704.

Almeida W.O., Silva-Souza A.T., Sales D.L. 2010: Parasitism of Phalloceros harpagos (Cyprinodontiformes: Poeciliidae) by Sebekia oxycephala (Pentastomida: Sebekidae) in the headwaters of the Cambé River, Paraná State, Brazil. Braz. J. Biol. 70: 457-458.

Barros L.A., Mateus L.A.F., Braum D.T., Bonaldo J. 2010: Ecological aspects of endoparasites in red piranha (Pygocentrus nattereri Kner, 1860) from Cuibá river, Mato Grosso, Brazil. Arq. Bras. Med. Vet. 62: 228-231.

Boyce W.M. 1985: The prevalence of Sebekia mississippiensis (Pentastomida) in American alligators (Alligator mississippiensis) in north Florida and experimental infection of paratenic hosts. Proc. Helminthol. Soc. Wash. 52: 278-282.

Boyce W.M., Cardeilhac P., Lane T., Buergelt C., King M. 1984: Sebekiosis in captive alligator hatchlings. J. Am. Vet. Med. Assoc. 185: 1419-1420.

Boyce W.M., Kazacos E.A., Kazacos K.R., Engelhardt J.A. 1987: Pathology of pentastomid infections (Sebekia mississippiensis) in fish. J. Wildl. Dis. 23: 689-692.

Bush A.O., Lafferty K.D., Lotz J.M., Shostak A.W. 1997: Parasitology meets ecology on its own terms: Margolis et al. Revisited. J. Parasitol. 83: 575-583.

Canada Department of Fisheries and Oceans Animal-User Training Template 2004: World Wide Web electronic publication, www.ccac.ca, 06/2013.

De Campos C.M., Da Fonseca V.E., Takemoto R.M., De Moreas F.R. 2008: Parasitic fauna of cachara Pseudoplatystoma fasciatum (Siluriformes: Pimelodidae) from the Aquidauana river, in the Pantanal of Mato Grosso do Sul State, Brazil. Acta Sci. - Biol. Sci., Univ. Estad. Maringá, Maringá, Brazil, 30: 91-96.

Carvalho L.N., Del Caro K., Takemoto R.M. 2003: Host-parasite interaction between branchiurans (Crustacea: Argulidae) and piranhas (Osteichtyes: Serrasalminae) in the Pantanal wetland of Brazil. Environ. Biol. Fish 67: 289-296.

Diesing K.M. 1836. Versuch einer Monographie der Gattung Pentastoma. Ann. Wiener Mus. Naturgesch. 1: 1-32.

Diesing K.M. 1850. Systema helminthum. Volume 1. Wilhelmum Braumüller, Vindobenae, 679 pp.

Fain A. 1961: Pentastomides de l'Afrique Centrale. Ann. Mus. Roy. Afr. Centr., Série 8, 92: 1-115.

FAIn A. 1975: The Pentastomida parasitic in man. Ann. Soc. Belg. Med. Trop. 55: 59-64.

Ferenc S.A., Tallevast T.L., Courtney C.H. 1986: Experimental infection of the brown water snake, Nerodia taxispilota, with Sebekia mississippiensis (Penatastomida). Proc. Helminthol. Soc. Wash. 53: 296-297.

Froese, R., Pauly, D. (Eds.) 2013: FishBase. World Wide Web electronic publication, www.fishbase.org, 08/2013.

GAIRHE K.P. 2007: An investigation on the causes of mortality in captive gharial hatchlings at the Chitwan National Park, Nepal. MSc thesis, Tribhuvan University, Nepal, 122 pp.

Guégan J.F., Hugueny B. 1994: A nested parasite species subset pattern in tropical fish: host as major determinant of parasite infracommunity structure. Oecologia 100: 184-189.

Guidelli G.M., IsaAc A., Takemoto R.M., Pavanelli G.C. 2003: Endoparasite infracommunities of Hemisorubim platyrhynchos (Valenciennes, 1840) (Pisces: Pimelodidae) of the Baía River, upper Paraná River floodplain, Brazil: specific composition and ecological aspects. Rev. Bras. Biol. 63: 261-268.

Heymons R. 1940a: Beiträge zur Systematik der Pentastomiden III. Pentastomiden mit spiralig gekrümmten Körperformen. Z. Parasitenkd. 2: 77-94.

Heymons R. 1940b: Ueber die Lebensweise der in Krokodilen vorkommenden Pentastomida. Sitz. Ges. Naturforsch. Freunde zu Berlin, 8-10: 253-269. 
Heymons R. 1941: Beiträge zur Systematik der Pentastomiden. VI. Die Arten der Gattung Alofia im Vergleich mit Sebekia. I. Übersicht über Arten. Z. Parasitenkd. 12: 419-423.

Heymons R., Vitzthum H.G. 1936: Beiträge zur Systematik der Pentastomiden. Z. Parasitenkd. 8: 1-103.

Holl F.J. 1928: A linguatulid parasite from North American fishes. J. Parasitol. 15: 63-66.

Junker K., Boomker J. 2002: Description of Pelonia africana n. g., n. sp. (Pentastomida: Sebekidae) from the lungs of Pelomedusa subrufa and Pelusios sinuatus (Chelonia) in South Africa. Onderstepoort J. Vet. Res. 69: 53-59.

Junker K., Boomker J., Booyse D.G. 1998a: Pentastomid infections in cichlid fishes in the Kruger National Park and the description of the infective larva of Subtriquetra rileyi n. sp. Onderstepoort J. Vet. Res. 65: 159-167.

JunKer K., Boomker J., Booyse D.G. 1998b: Experimental studies on the life-cycle of Sebekia wedli (Pentastomida: Sebekidae). Onderstepoort J. Vet. Res. 65: 233-237.

Junker K., Boomker J., Swanepoel D., Taraschewski H. 2000: Leiperia cincinnalis Sambon, 1922 from Nile crocodiles Crocodylus niloticus in the Kruger National Park, South Africa, with a description of the male. Syst. Parasitol. 47: 29-41.

Junker K., Riley J., Boomker J. 2003: Redescription of Diesingia megastoma (Diesing, 1836) Sambon, 1922, a pentastomid parasite from the South American terrapin Hydromedusa tectifera. Syst. Parasitol. 56: 211-218.

Ladds P.W., Sims L.D. 1990: Diseases of young captive crocodiles in Papua New Guinea. Aust. Vet. J. 67: 323-330.

Leuckart R. 1860: Bau und Entwicklungsgeschichte der Pentastomen nach Untersuchungen besonders von Pent. taenioides und $P$. denticulatum. C.F Winter'sche Verlagshandlung, Leipzig, $160 \mathrm{pp}$.

LOHRMANN E. 1889: Untersuchungen über den anatomischen Bau der Pentastomen. Arch. Naturgesch. 1: 303-337.

Luus-Powell W.J., Jooste A., Junker K. 2008: Pentastomid parasites in fish in the Olifants and Incomati River systems, South Africa. Onderstepoort J. Vet. Res. 75: 323-329.

Mairena H., Solano M., Venegas W. 1989: Human dermatitis caused by a nymph of Sebekia. Am. J. Trop. Med. Hyg. 41: 352-354.

Overstreet R.M., Self J.T., Vliet K.A. 1985: The pentastomid Sebekia mississippiensis sp. $\mathrm{n}$. in the American alligator and other hosts. Proc. Helminthol. Soc. Wash. 52: 266-277.

Rego A.A., Eiras J. 1989: Identificação das larvas de Sebekia e Leiperia (Pentastomida) histopatologia em peixes de rios. Rio de Janeiro, RJ. Rev. Bras. Biol. 49: 591-595.

Riley J. 1986: The biology of pentastomids. Adv. Parasitol. 25: 45-128.

Riley J. 1994: A revision of the genus Alofia Giglioli, 1922 and a description of a new monotypic genus, Selfia: two genera of pentastomid parasites (Porocephalida: Sebekidae) inhabiting the bronchioles of the marine crocodile Crocodylus porosus and other crocodilians. Syst. Parasitol. 29: 23-41.

Riley J., Hill G.F., Huchzermeyer F.W. 1997: A description of Agema, a new monotypic pentastomid genus from the lungs of the African dwarf and slender-snouted crocodiles. Syst. Parasitol. 37: 207-217.

Riley J., Huchzermeyer, F.W. 1995a: Description of four species of pentastomid parasites belonging to the genera Alofia Giglioli, 1922 and Sebekia Sambon, 1922, from a single Nile crocodile Cocodylus niloticus from Botswana. Syst. Parasitol. 31: $221-238$

Riley J., Huchzermeyer, F.W. 1995b: Pentastomid parasites of the family Sebekidae Fain, 1961 in West African dwarf crocodiles Osteolaemus tetraspis Cope, 1851 from the Congo, with a description of Alofia parva n. sp. Onderstepoort J. Vet. Res. 62: $151-162$.

Riley J., Huchzermeyer F.W. 1996: A reassessment of the pentastomid genus Leiperia Sambon, 1922 with a description of a new species from both the Indopacific crocodile Crocodylus porosus and Johnston's crocodile C. johnstoni in Australia. Syst. Parasitol. 34: 53-66.

Riley J., Huchzermeyer F.W. 2000: Diet and lung parasites of swamp forest dwarf crocodiles (Osteolaemus tetraspis osborni) in the northern Congo Republic. Copeia 2: 582-586.

Riley J., OAKs J.L., Gilbert M. 2003: Raillietiella trachea $\mathrm{n}$. sp., a pentastomid from the trachea of an oriental white-backed vulture Gyps bengalensis taken in Pakistan, with speculation about its life-cycle. Syst. Parasitol. 56: 155-161.

Riley J., Spratt D.M., Winch, J.M. 1990: A revision of the genus Sebekia Sambon, 1922 (Pentastomida) from crocodilians with descriptions of five new species. Syst. Parasitol. 16: 1-25.

SAmbon L.W. 1922: A synopsis of the family Linguatulidae. J. Trop. Med. Hyg. 25: 188-206 + 391-428.

SAS Institute, Inc. 1999: Users's Guide, version 9, $1^{\text {st }}$ printing, Volume 2. SAS Institute Inc., SAS Campus Drive, Cary, North Carolina 27513.

Sazima I., Machado, F.A. 1990: Underwater observations of piranhas in western Brazil. Environ. Biol. Fish. 28: 17-31.

Self J.T., Kuntz R.E. 1967: Host-parasite relations in some Pentastomida. J. Parasitol. 53: 202-206.

Self J.T., Rego A.A. 1985: Reassessments and revisions of certain genera and species of the family Sebekidae (Pentastomida) including description of Sebekia microhamus n. sp. Syst. Parasitol. 7: 33-41.

Shapiro S.S., Wilk M.B. 1965: An analysis of variance test for normality (complete samples). Biometrika 52: 591-611.

Shipley A.E. 1898: An attempt to revise the family Linguatulidae. Arch. Parasitol. 1: 52-80.

Tanaka L.K. 2000: Aspectos ecológicos dos parasitos de Serrasalmus marginatus Valenciennes, 1847 e Serrasalmus spilopleur Kner, 1860 (Characiformes, Serrasalmidae) do rio Baía, planície de inundação do alto rio Paraná, MS. MSc thesis, Universidade Estuadal de Maringá, Maringá, 32 pp.

Travassos L. 1924: Sebekia du poumon des crocodiles d'Amerique. Compt.-Rend. Hebd. Seances Mem. Soc. Biol. 90: 239240. Cited after Riley et al. (1990)

VARGaS M.V. 1975: Descripción del huevecillo, larva y ninfa de Subtriquetra subtriquetra Sambon, 1922 (Pentastomida), y algunas observations sobre su ciclo de vida. Rev. Biol. Trop. 23: $67-75$.

Winch J.M., Riley, J. 1986a: Morphogenesis of larval Sebekia oxycephala (Pentastomida) from a South American crocodilian (Caiman sclerops) in experimentally infected fish. Z. Parasitenkd. 72: 251-264.

WinCH J.M., RiLEY, J. 1986b: Studies on the behaviour, and development in fish, of Subtriquetra subtriquetra: a uniquely freeliving pentastomid larva from a crocodilian. Parasitology 93: 81-98. 